\title{
Pulse Reversal PermAlloy Plating Process for MEMS Applications
}

\author{
Smistrup, Kristian; Tang, Peter Torben; Møller, Per
}

Published in:

E C S Transactions

Link to article, DOI:

$10.1149 / 1.2753252$

Publication date:

2007

Document Version

Publisher's PDF, also known as Version of record

Link back to DTU Orbit

Citation (APA):

Smistrup, K., Tang, P. T., \& Møller, P. (2007). Pulse Reversal PermAlloy Plating Process for MEMS Applications. E C S Transactions, 3(25), 179-189. https://doi.org/10.1149/1.2753252

\section{General rights}

Copyright and moral rights for the publications made accessible in the public portal are retained by the authors and/or other copyright owners and it is a condition of accessing publications that users recognise and abide by the legal requirements associated with these rights.

- Users may download and print one copy of any publication from the public portal for the purpose of private study or research.

- You may not further distribute the material or use it for any profit-making activity or commercial gain

- You may freely distribute the URL identifying the publication in the public portal

If you believe that this document breaches copyright please contact us providing details, and we will remove access to the work immediately and investigate your claim. 


\title{
Pulse Reversal Permalloy Plating Process for MEMS Applications
}

\author{
K. Smistrup ${ }^{\mathrm{a}}, \mathrm{P} . \mathrm{T}$. Tang ${ }^{\mathrm{b}}$, and P. Møller ${ }^{\mathrm{b}}$ \\ ${ }^{a}$ MIC - Department of Micro and Nanotechnology \\ ${ }^{\mathrm{b}}$ Department of Manufacturing Engineering and Management (IPL) \\ Technical University or Denmark, DK-2800 Kgs. Lyngby, Denmark
}

\begin{abstract}
Nickel-iron, and especially Permalloy, plating has been known and used for more than 40 years, but there are still several problems related to stability and maintenance that should be resolved. This paper presents a saccharine-free pulse reversal plating Permalloy electrolyte, which gives low-stress deposits. We demonstrate selected MEMS applications of the electrolyte. The use of the strong complexing agent 5-sulfosalicylic acid allows for a photometric determination of the $\mathrm{Fe}^{3+}$-level in the bath and eliminate precipitates. This makes the electrolyte suitable as a Permalloy plating process used on an irregular basis.
\end{abstract}

\section{Introduction}

Electroplating of nickel-iron alloys has been known for many years. IBM filed some of the first patents aiming at deposition of soft magnetic films around $1970(1,2)$. At that time the preferred plating bath for electrodeposition of nickel-iron alloys, and particularly the $\mathrm{Ni}_{80} \mathrm{Fe}_{20}$ or Permalloy, consisted of simple mixtures of the sulfate or chloride salts of nickel and iron. The typical bath would furthermore contain boric acid as a $\mathrm{pH}$ buffer and a few organic additives such as lauryl sulfate (wetting agent) and saccharin (stress reducer). Especially when chloride salts are used, the internal stresses in the deposits are very high and must be reduced using efficient stress reducing additives. Unfortunately, the use of the so-called sulfur containing additives results in small amounts of sulfur being co-deposited (up to a few percent). Even a small sulfur content will influence the corrosion resistance (3), as well as both the mechanical and the magnetic properties, in a negative way.

In order to reduce the internal stress, or to avoid the use of sulfur containing stress reducing additives, some authors have reported Permalloy plating processes based on sulphamate rather than sulfate (and chloride) (4).

The mechanism of nickel-iron alloy plating belong to the so-called anomalous type (5) which means that the iron is plated preferentially although it is not the most noble metal of the two. The degree of anomalous deposition depends on bath temperature (5) but also on $\mathrm{pH}$ and the use of $\mathrm{pH}$-buffers (6). A bath without $\mathrm{pH}$-buffer is less anomalous in behavior as compared to a bath with $0.4 \mathrm{M}$ of boric acid (6). According to the literature (5), but also the experience obtained within the present work, simple sulfate or chloride based Permalloy baths, should be operated in a $\mathrm{pH}$ range from 3 to 5 . Much below 3 the current efficiency will drop to unacceptable values, see also (6), and above 5 the formation of $\mathrm{Fe}^{3+}$-based precipitates will slowly destroy the electrolyte. Adding a suitable complexing agent for $\mathrm{Fe}^{3+}$ postpones the formation of ferric compounds. Venkatasetty (7) reports that the addition of citrate (to an otherwise simple sulfate bath) will increase the 
period in which good deposits can be obtained from a few hours to more than 25 hours. Depending on the complexing agent, it may also have the effect that the iron to "total metal" concentration ratio can be increased from 2 percent to 4 percent or more - while still depositing the desired Permalloy composition. As most baths use pure nickel anodes, having a relatively high iron concentration in the bath will make the bath easier to operate and less susceptible to small concentration changes.

Electroplated Permalloy has several applications in MEMS technology. Permalloy is widely used when some form of magnetic actuation is required, such as magnetically actuated valves or flux guides in electromagnet applications (see for example (8-12)). In recent years magnetic manipulation in microfluidic systems has emerged as a promising technology for bio-separation in lab-on-a-chip systems. A receptor molecule (DNA, RNA, proteins, cells, antigens etc.) is bound on the surfaces on magnetic beads or particles. These beads or particles are attracted to regions of large magnetic field, and thus if they are suspended in a solution containing target molecules for the receptor molecules, the target molecules can be separated from the solution by application of a spatially varying magnetic field. Both active systems with on-chip electromagnets and passive systems with on-chip soft magnetic structures have been realized using electroplated Permalloy (see $(13,14)$ and references therein). The microsystems described in refs. (13-15) are all fabricated using the electrolyte presented in this paper.

One key requirement for a MEMS-compatible deposit is that it should have relatively low internal stress. Many MEMS-structures contain thin beams or membranes that will not react well to stress, and in other cases thick films are needed, and a large internal stress might make such films peel off.

The permalloy plating bath we present here has been used to plate $150 \mu \mathrm{m}$ thick bars with widths of $50 \mu \mathrm{m}$ and lengths of $4.5 \mathrm{~mm}$ without any peel off. We have not measured the stress of deposits made with this bath, but in (16) a similar pulse reversal plating bath for $\mathrm{CoNiFe}$ is presented, where the stress is measured to be approximately $70-80 \mathrm{Mpa}$, which is relatively low.

\section{Experimental Methods}

\begin{tabular}{|lcc|}
\hline \multicolumn{2}{|l|}{ TABLE I. Recipe for the Permalloy electrolyte. The $\mathrm{pH}$-value was adjusted to 3.0 using sodium hydroxide. The } \\
bath was operated at $35^{\circ} \mathrm{C}$. & \multicolumn{1}{c|}{ Formula } & Concentration (M) \\
\hline Compound & $\mathrm{NiSO}_{4} \cdot 6 \mathrm{H}_{2} \mathrm{O}$ & 0.2000 \\
\hline Nickel sulfate & $\mathrm{NiCl}_{2} \cdot 6 \mathrm{H}_{2} \mathrm{O}$ & 0.2000 \\
Nickel chloride & $\mathrm{FeSO}_{4} \cdot 7 \mathrm{H}_{2} \mathrm{O}$ & 0.0293 \\
Iron Sulfate & $\mathrm{H}_{3} \mathrm{BO}_{3}$ & 0.5000 \\
Boric acid & $\mathrm{HO}_{3} \mathrm{~S}_{6} \cdot \mathrm{C}_{6} \mathrm{OH} \cdot \mathrm{COOH}$ & 0.0350 \\
5-sulfosalicylic acid & $\left(\mathrm{NaO}_{3} \mathrm{~S}\right)_{3} \mathrm{C}_{10} \mathrm{H}_{8}$ & 0.0070 \\
Naphthalene tri-sulfonic acid (sodium salt) &
\end{tabular}

The main stability problem associated with alloy plating baths containing iron, is the oxidation of $\mathrm{Fe}^{2+}$ to $\mathrm{Fe}^{3+}$ and the following formation of strong hydroxide complexes (see TABLE II) leading to precipitation of $\mathrm{Fe}(\mathrm{OH})_{3}$. The complexing agent 5-sulfosalicylic acid, is one of very few candidates for a compound forming complexes with $\mathrm{Fe}^{3+}$ that are stronger than the hydroxides. In TABLE II the formation constants of oxalate, which is usually regarded as a strong complexing agent for $\mathrm{Fe}^{3+}$, is clearly weaker than 5sulfosalicylic acid. 


\begin{tabular}{|c|c|c|c|c|}
\hline Metal ion & Ligand & $\log K_{1}$ & $\log K_{2}$ & $\log K_{3}$ \\
\hline $\mathrm{Fe}^{2+}$ & $\mathrm{OH}^{-}$ & 5.56 & 9.77 & 9.67 \\
\hline $\mathrm{Fe}^{3+}$ & $\mathrm{OH}^{-}$ & 11.87 & 21.17 & 29.67 \\
\hline $\mathrm{Ni}^{2+}$ & $\mathrm{OH}^{-}$ & 4.97 & 8.55 & 11.33 \\
\hline $\mathrm{Fe}^{2+}$ & $\mathrm{HO}_{3} \mathrm{~S} \cdot \mathrm{C}_{6} \mathrm{H}_{3} \mathrm{OH} \cdot \mathrm{COOH}$ & 5.90 & & \\
\hline $\mathrm{Fe}^{3+}$ & $\mathrm{HO}_{3} \mathrm{~S} \cdot \mathrm{C}_{6} \mathrm{H}_{3} \mathrm{OH} \cdot \mathrm{COOH}$ & 14.64 & 25.18 & 32.12 \\
\hline $\mathrm{Ni}^{2+}$ & $\mathrm{HO}_{3} \mathrm{~S} \cdot \mathrm{C}_{6} \mathrm{H}_{3} \mathrm{OH} \cdot \mathrm{COOH}$ & 6.42 & 10.24 & \\
\hline $\mathrm{Fe}^{2+}$ & $\mathrm{C}_{2} \mathrm{O}_{4}{ }^{2-}$ & 2.9 & 4.52 & 5.22 \\
\hline $\mathrm{Fe}^{3+}$ & $\mathrm{C}_{2} \mathrm{O}_{4}{ }^{2-}$ & 9.4 & 16.2 & 20.2 \\
\hline $\mathrm{Ni}^{2+}$ & $\mathrm{C}_{2} \mathrm{O}_{4}{ }^{2-}$ & 5.3 & 7.64 & $\sim 8.5$ \\
\hline
\end{tabular}

The use of 5-sulfosalicylic acid, and a few other related compounds, in iron alloy plating baths was patented in 1978 (18). Besides the capabilities as complexing agent, other advantages of 5-sulfosalicylic acid include a very strong red color (absorbance at $480 \mathrm{~nm}$ ) of the complexes with $\mathrm{Fe}^{3+}$ and that 5-sulfosalicylic aced is a stable molecule which is not destroyed in the electrolyte and does not seem to cause co-deposit of sulfur or carbon.

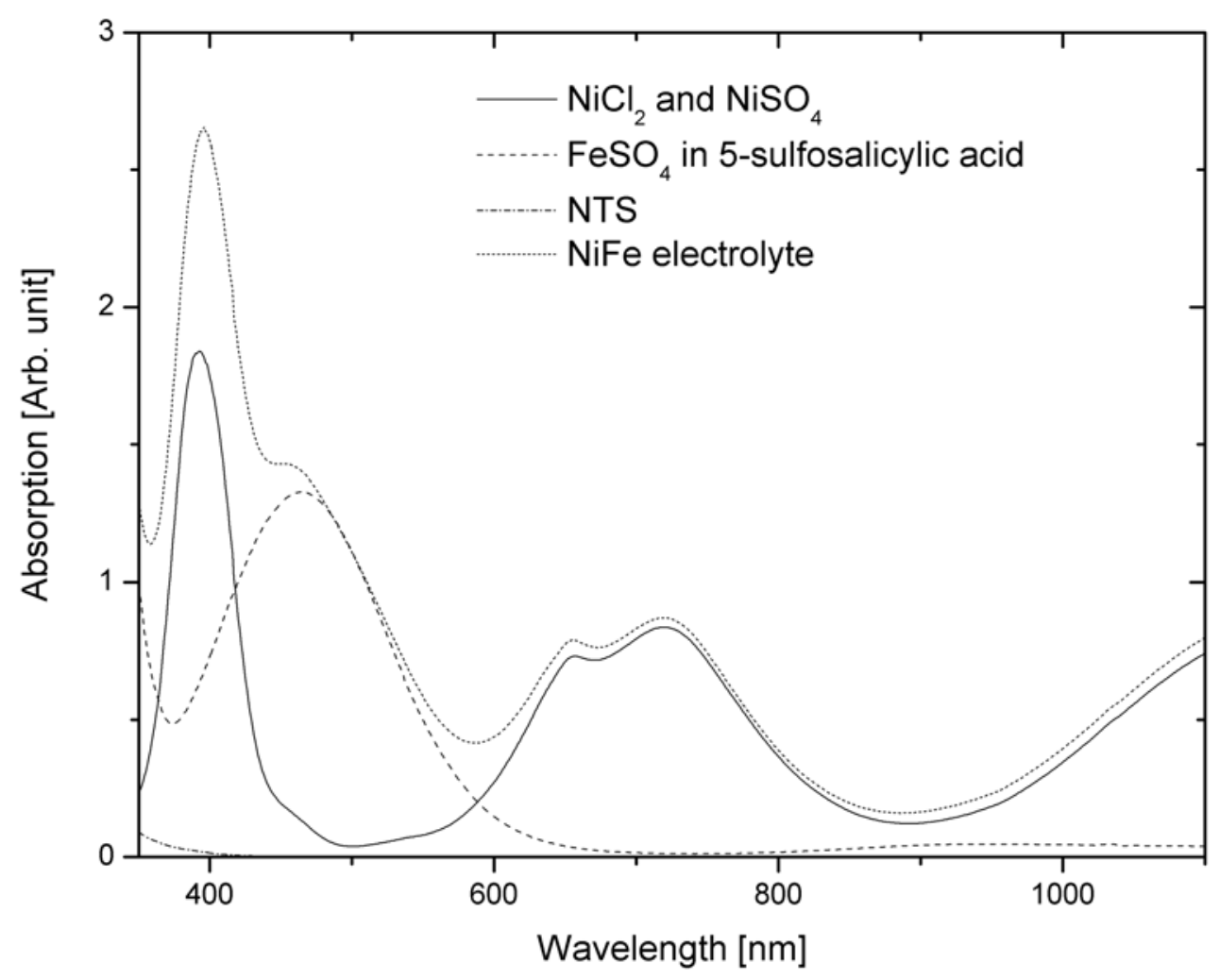

Figure 1: Spectrophotometric data for the components of the Permalloy electrolyte. The data for the individual components add up to give the data for the finished electrolyte.

Initially 2 liters of bath were mixed using the recipe of TABLE I. During the mixing process the spectrophotometric data for each of the components were measured (see Figure 1) in the range $350 \mathrm{~nm}$ to $1100 \mathrm{~nm}$ using a Shimadzu UV mini 1240 
Spectrophotometer. The mixed bath was split into two 1-litre bottles. One was used as the plating bath, and the other was used for reference.

These two baths were used to study of the development of the electrolyte over time. Once a week for eight weeks, Permalloy was electroplated onto a $3 \times 3 \mathrm{~cm}^{2}$ copper plate for 30 minutes using pulse reversal plating with the cathodic pulse being $60 \mathrm{~ms}$ of $4 \mathrm{~A} / \mathrm{dm}^{2}$ and the anodic pulse being $20 \mathrm{~ms}$ of $6 \mathrm{~A} / \mathrm{dm}^{2}$ corresponding to an average current density of $1.5 \mathrm{~A} / \mathrm{dm}^{2}$. Absorbance, as well as $\mathrm{pH}$, was recorded in the plating bath before and after each deposition. At the same time similar data were also measured for the reference bath. $\mathrm{pH}$ was measured using an Accumet model $15 \mathrm{pH}$-meter using a Radiometer pHC2001 electrode.

Two other baths were mixed to establish the connection between spectrophotometric data and the concentration of $\mathrm{Fe}^{3+}$ and $\mathrm{Fe}^{2+}$ ions in solution. $800 \mathrm{ml}$ of bath was mixed using the recipe of TABLE I without the iron sulfate. This was split into two $400 \mathrm{ml}$ portions, and $0.0293 \mathrm{M} \mathrm{FeSO}_{4}$ was added to one portion, and $0.01465 \mathrm{M} \mathrm{Fe}_{2}\left(\mathrm{SO}_{4}\right)_{3}$ was added to the other, such that the amount of Fe ions was the same in the two solutions. This gave two baths; one containing $\mathrm{Fe}^{2+}$ ions only - the regular bath, and one containing $\mathrm{Fe}^{3+}$ ions only. These two baths were mixed in various ratios to determine the absorbance at $480 \mathrm{~nm}$ as a function of $\mathrm{Fe}^{3+}$-content.

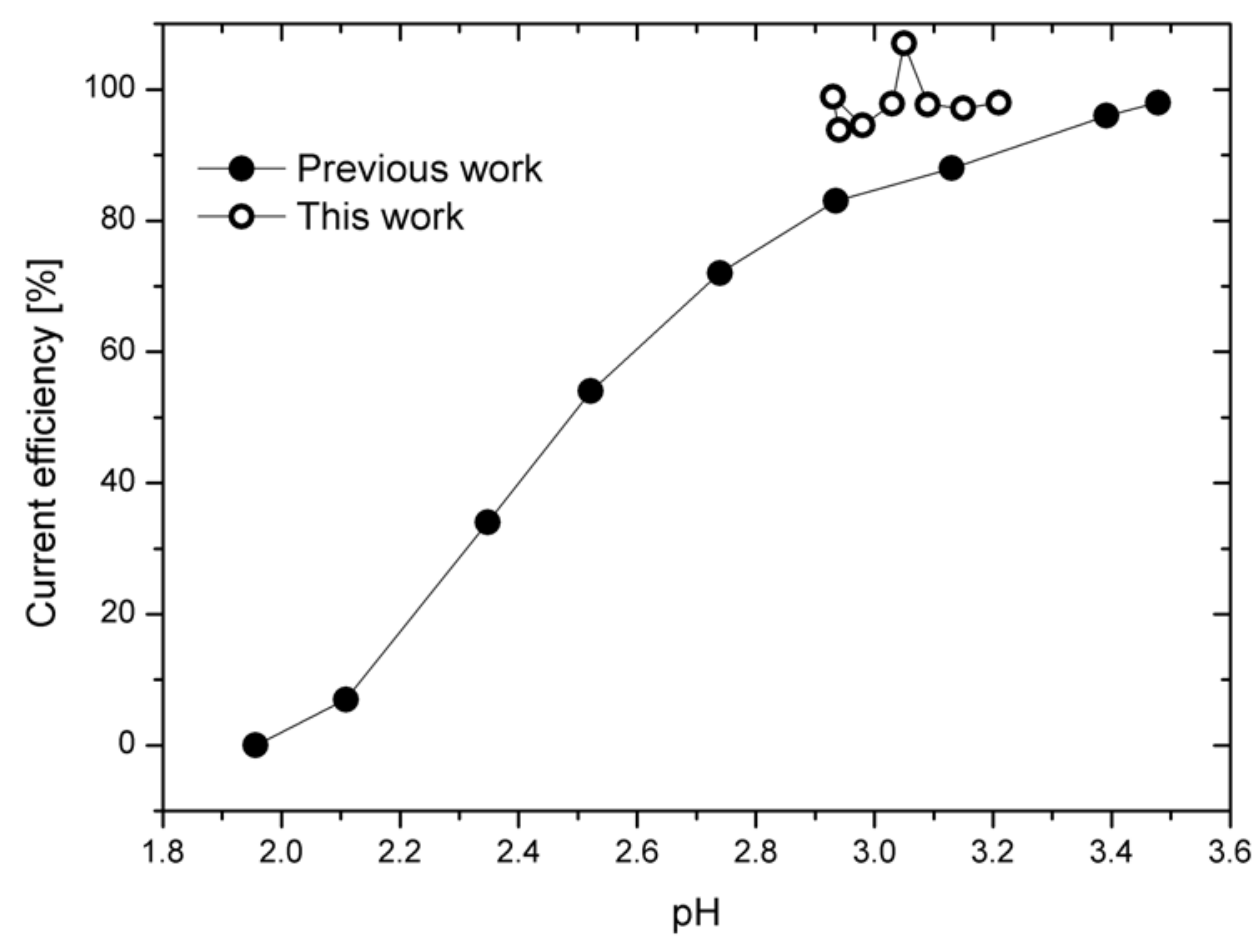

Figure 2: Current efficiency as a function of $\mathrm{pH}$. Results from this work are compared to previous work (19) using almost identical electrolytes.

The current efficiency was established by weighing the samples before and after the electroplating using a Sartorius BP61 scale with a maximum precision of $\pm 0.1 \mathrm{mg}$. The $\mathrm{Fe}$ (and $\mathrm{Ni}$ ) content in the deposits was determined semi-quantitatively with standardless energy dispersive X-Ray spectrometry (EDX, Oxford Scientific) in a JEOL Scanning electron microscope (SEM, JSM-5900). 


\section{Results and Discussion}

Korsbæk and Rubæk previously developed the current recipe for the Permalloy electroplating bath in collaboration with Hansen and Tang (19). They established the relation between $\mathrm{pH}$ of the bath and current efficiency (see Figure 2). These results are compared to results obtained during the present investigation. There is a relatively good correlation between the old results and the new ones. The only differences between the experiments are a higher chloride content in the new bath (called "This work" in Figure 2) and that in this work we did not compensate for a known inaccuracy in the pulse plating rectifier (TCD research, double cathode WinCAPP) when operating at small currents.

In Ref. (15) we report the magnetic properties and fabrication scheme of a magnetic separation system that was fabricated using the present electrolyte.

The spectrophotometric data for the different bath components were measured on the individual components and in an unused electrolyte with the composition presented in TABLE I. It is seen in Figure 1 how the curves for the individual components add up to give the total curve for the bath. Also, it is seen that the Fe sulfate has a distinct peak at $480 \mathrm{~nm}$, whereas Ni have several peaks at 393, 657 and $720 \mathrm{~nm}$ (see Figure 1). This means that we can distinguish the Fe peak from the nickel peaks, and thus we can monitor the development of the different components.

Figure 3: Development in the spectrophotometric data over time. The graph also shows how the spectrophotometric data change during electroplating.

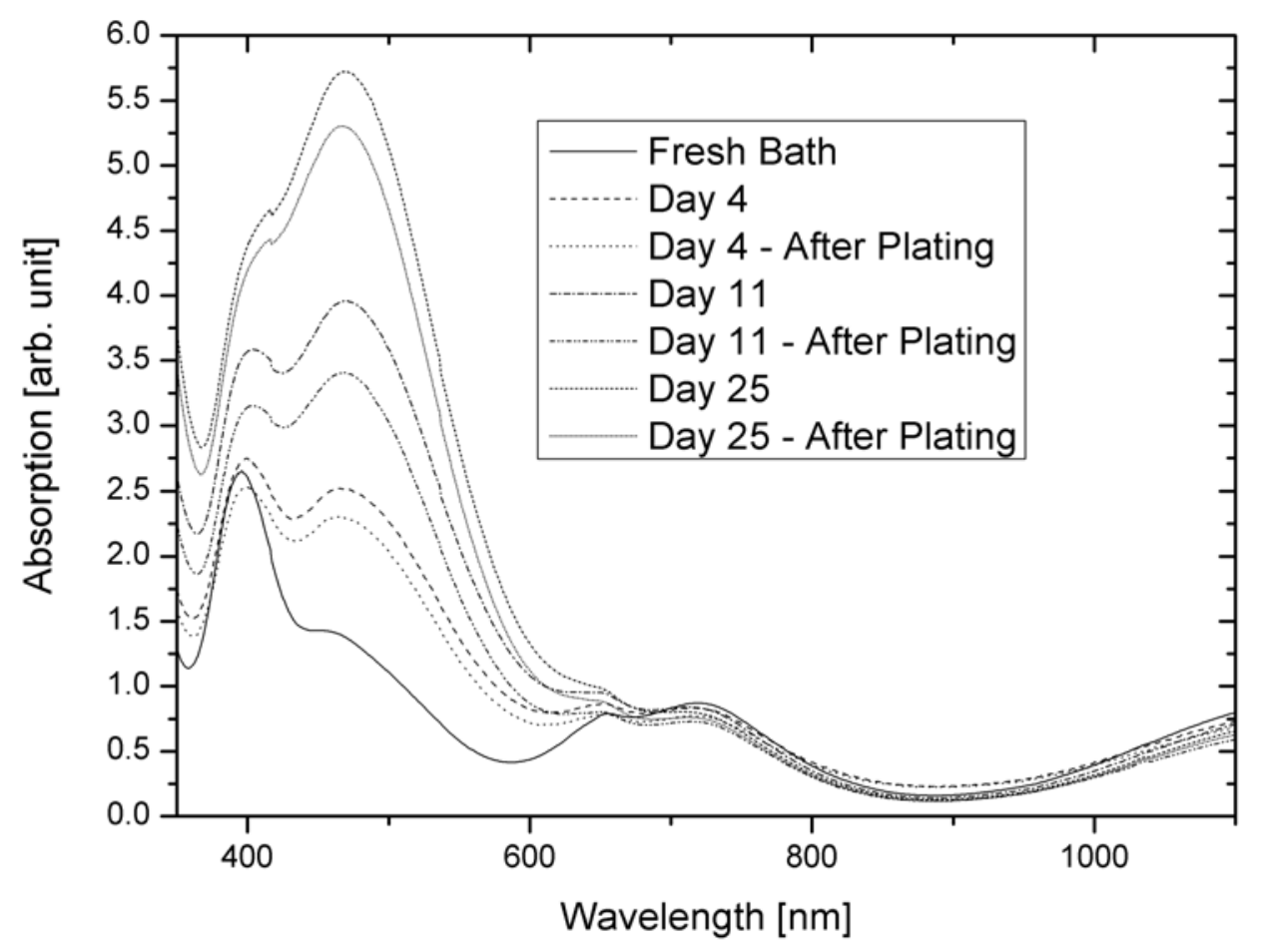

Figure 3: Development in the spectrophotometric data over time. The graph also shows how the spectrophotometric data change during electroplating. 
We have monitored the development of the spectrophotometric data over time. Figure 3 displays our findings. It is seen that the Fe peak grows rapidly. Within 25 days it has grown to a state, where it completely dominates the entire spectrum. It is well-known that $\mathrm{Fe}^{2+}$ and $\mathrm{Fe}^{3+}$ absorb at the same wavelength, but $\mathrm{Fe}^{3+}$ absorbs much more strongly than $\mathrm{Fe}^{2+}$. Therefore the rise in the peak is interpreted as a sign that some of the $\mathrm{Fe}^{2+}$ ions have been oxidized to $\mathrm{Fe}^{3+}$. Also, we see that the Fe peak at $480 \mathrm{~nm}$ is reduced after plating. This means that some of the $\mathrm{Fe}^{3+}$ ions are removed (deposited or more likely reduced to $\mathrm{Fe}^{2+}$ ) during the plating process.

In Figure 4 the data for the absorption at $480 \mathrm{~nm}$ and the $\mathrm{pH}$-value of the plating bath before and after plating are compared with data for an unused reference bath. We see that the absorption grows steadily and that the plating bath grows slightly faster than the reference bath. This may be due to the fact that the plating bath was exposed more to air than the reference bath. It is also seen that the plating process consistently causes the absorption to drop - at least temporarily - which indicates that $\mathrm{Fe}^{3+}$ ions are reduced to $\mathrm{Fe}^{2+}$ ions during plating.

We also learn from Figure 4 that $\mathrm{pH}$ rises substantially during electrodeposition such that $\mathrm{pH}$ is enhanced just after plating, but during the time before the next experiment (around one week) $\mathrm{pH}$ drops back to a value that is only a little higher than before the previous experiment. On the other hand $\mathrm{pH}$ in the reference bath is consistently falling, even if the total change is small.

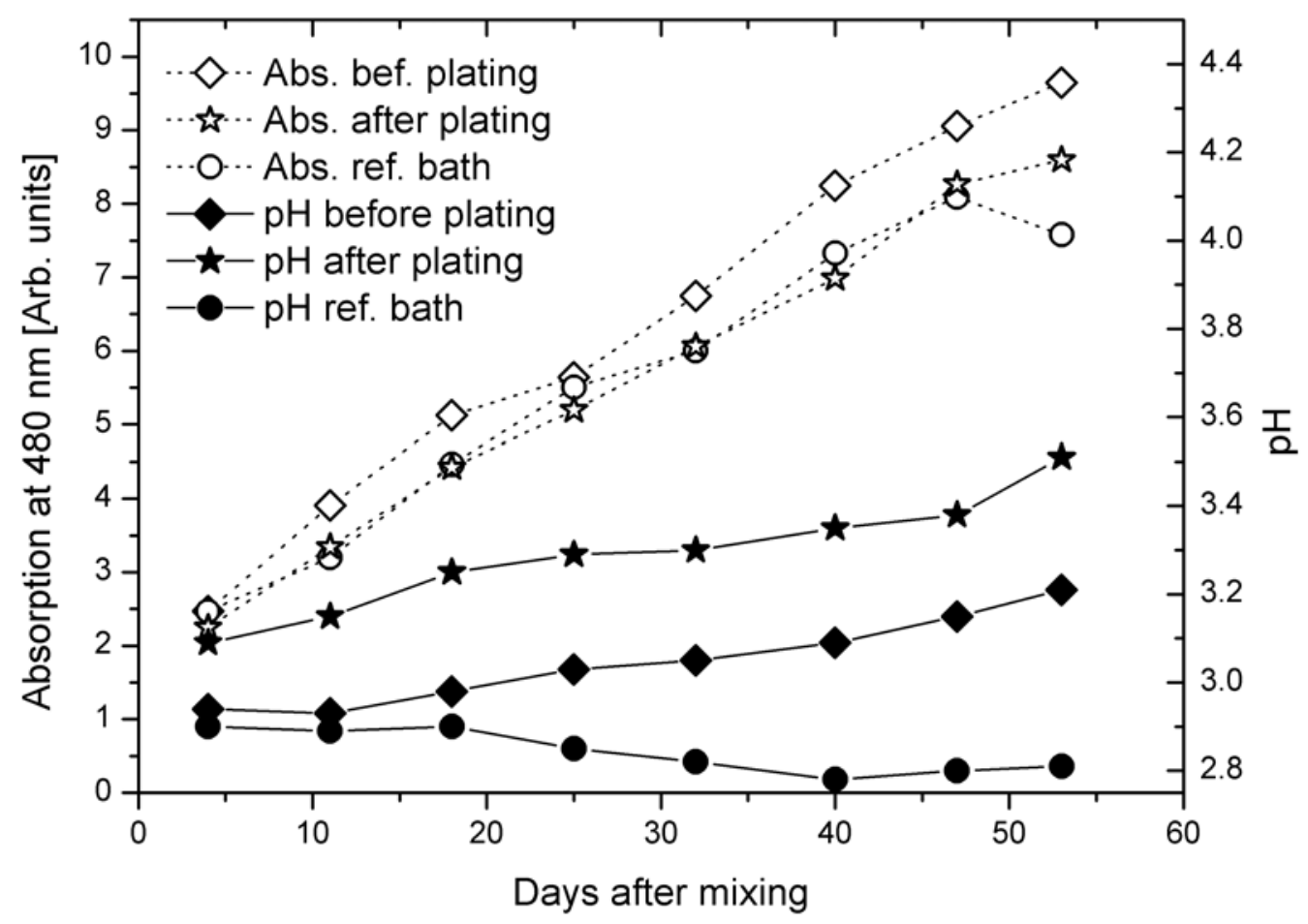

Figure 4: Development of the characteristic spectrophotometric peak at $480 \mathrm{~nm}$ (left axis) and $\mathrm{pH}$ (right axis) as function of time. Data is shown before and after plating as well as for the unused reference bath. A total of 8 plating experiments were conducted. 
During the electrodeposition, although pulse reversal plating is applied and thus makes many reactions possible, the dominating or resulting electrochemical reactions are:

$$
\begin{aligned}
& 2 \mathrm{H}^{+}+2 \mathrm{e}^{-} \rightarrow \mathrm{H}_{2}(\mathrm{~g}) \\
& \mathrm{Fe}^{3+}+\mathrm{e}^{-} \rightarrow \mathrm{Fe}^{2+} \\
& \mathrm{Fe}^{2+}+2 \mathrm{e}^{-} \rightarrow \mathrm{Fe} \\
& \mathrm{Ni}^{2+}+2 \mathrm{e}^{-} \rightarrow \mathrm{Ni}
\end{aligned}
$$

Reactions [1] and [2] are directly responsible for the current efficiency being in the range from 94-98\% (see Figure 2), whereas reactions [3] and [4] are the ones leading to the actual deposit.

After electrodeposition, when the solution is resting in a closed PE bottle, the following reaction is anticipated:

$$
4 \mathrm{Fe}^{2+}+\mathrm{O}_{2}+4 \mathrm{H}^{+} \rightarrow 4 \mathrm{Fe}^{3+}+2 \mathrm{H}_{2} \mathrm{O}
$$

Following this oxidation, we expect a protolysation-like process to take place. The exact role of 5-sulfosalicylic acid and the complexes formed during and after electrodeposition, as compared to the protolysation reactions when water is acting as a ligand (see reactions [6] and [7] below), is somewhat unclear.

$$
\begin{aligned}
& \mathrm{Fe}\left(\mathrm{H}_{2} \mathrm{O}\right)_{6}{ }^{3+} \rightarrow \mathrm{Fe}\left(\mathrm{H}_{2} \mathrm{O}\right)_{5}(\mathrm{OH})^{2+}+\mathrm{H}^{+}, \quad \mathrm{K}_{1}=9.0 \cdot 10^{-4}(20), \\
& \mathrm{Fe}\left(\mathrm{H}_{2} \mathrm{O}\right)_{5}(\mathrm{OH})^{2+} \rightarrow \mathrm{Fe}\left(\mathrm{H}_{2} \mathrm{O}\right)_{4}(\mathrm{OH})_{2}^{+}+\mathrm{H}^{+}, \quad \mathrm{K}_{2}=5.5 \cdot 10^{-4}(20) .
\end{aligned}
$$

Reaction [2] explains why the absorption at $480 \mathrm{~nm}$ decreases during electroplating, since it predicts that the $\mathrm{Fe}^{3+}$ content of the bath decreases during electroplating. The reaction in [5] explains why we see the general rise in absorption at that wavelength and thus $\mathrm{Fe}^{3+}$ content over time. There is not enough 5-sulfosalicylic acid in the bath to form complexes with all the metal ions, but it will most likely form complexes with all $\mathrm{Fe}^{3+}$ ions. Therefore complexes between $\mathrm{Fe}^{2+}$ and $\mathrm{Ni}^{2+}$ with water, $\mathrm{OH}^{-}$, and $\mathrm{Cl}^{-}$will also be present and protolysis may occur with these complexes as well. This combined with reactions [6] and [7] explains why we see a general decrease in $\mathrm{pH}$ in the reference bath. We expect that reaction [1] is the cause of the general increase in $\mathrm{pH}$ for the plating bath.

Just after the electroplating, $\mathrm{pH}$ has risen to a level that is substantially above the level before plating. We expect that this be due to the reaction [2], since the $\mathrm{Fe}^{3+}$ has to be released from the complexes formed in reactions like [6] and [7] which will release $\mathrm{OH}^{-}$that will quickly recombine with $\mathrm{H}^{+}$, and thus $\mathrm{pH}$ rises. Complexes formed with $\mathrm{Ni}^{2+}$ and $\mathrm{Fe}^{2+}$ and 5-sulfosalicylic acid as well as the other bath ingredients may also contribute to this $\mathrm{pH}$ rise, when the complexes are dissociated during electroplating.

In order to quantify the rise in absorption at $480 \mathrm{~nm}$ and relate it to the concentration of $\mathrm{Fe}^{3+}$ ions in the solution, we measured the absorption at different known concentrations of $\mathrm{Fe}^{3+}$ and $\mathrm{Fe}^{2+}$. The results are displayed in Figure 5. We have made a linear fit 
based on the first three data points. Another fit is made based on the last 4 data points. It is not uncommon for the absorption to 'fall off' at high absorption values due to screening.

The standard curve in Figure 5 allow us to calculate the concentration of $\mathrm{Fe}^{3+}$ ions in the bath, and by measuring the mass and chemical composition of the deposits, we are able to calculate the amount of remaining $\mathrm{Fe}^{2+}$ ions in the bath.

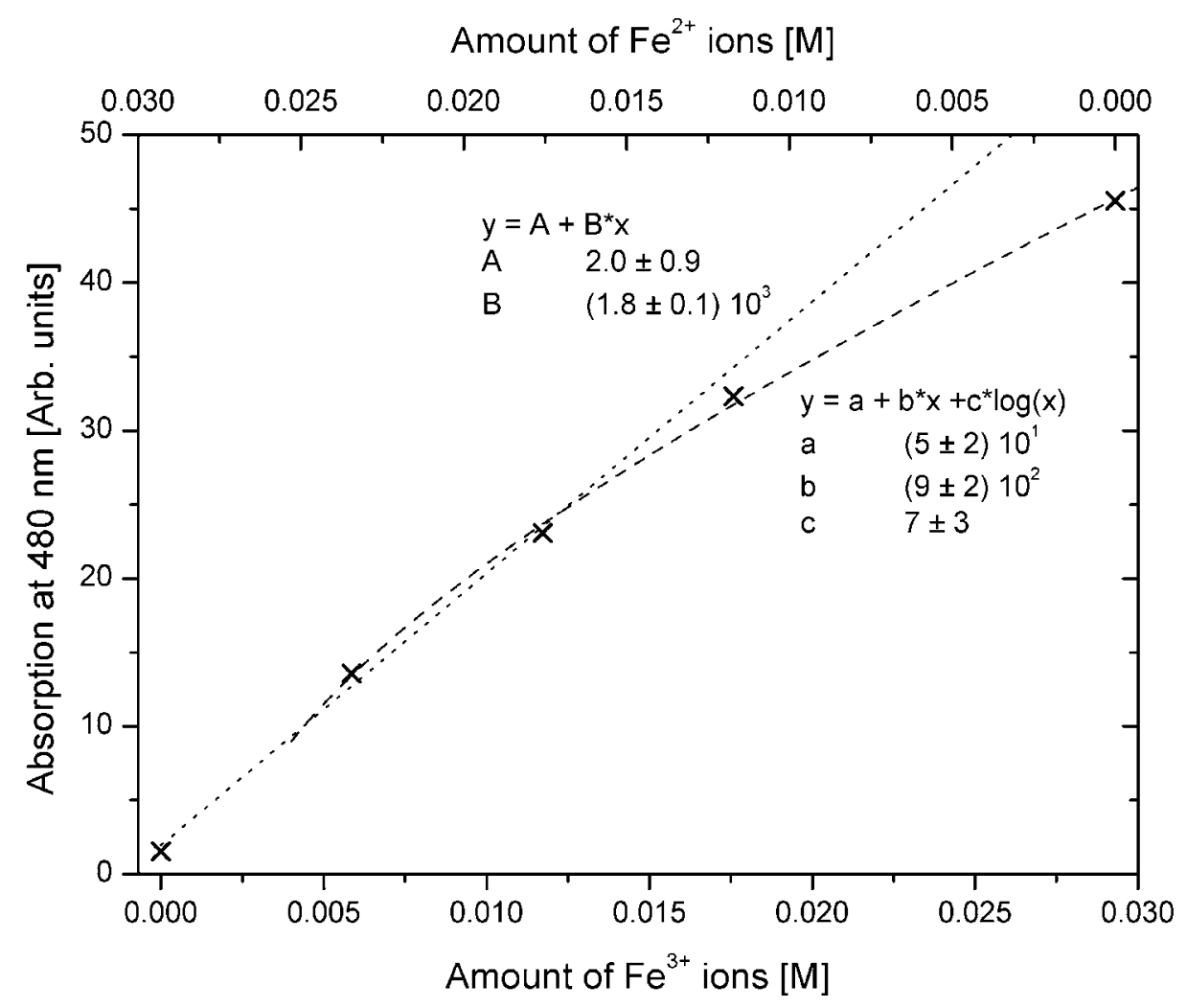

Figure 5: Absorption at $480 \mathrm{~nm}$ as a function of $\mathrm{Fe}^{3+}$ (and $\mathrm{Fe}^{2+}$ ) concentration. For concentrations below $0.01 \mathrm{M}$ a linear fit is used. In the fits ' $\mathrm{y}$ ' denotes the absorption, and ' $x$ ' denotes the amount of $\mathrm{Fe}^{3+}$ ions. Suitable units are assumed on 'A', 'B', 'a', 'b', and 'c'.

These data are collected in Figure 6. Over the course of eight weeks and 8 experiments, over $20 \%$ of the originally available $\mathrm{Fe}^{2+}$ ions have disappeared due to deposition or oxidation.

In Figure 7 the amount of $\mathrm{Fe}^{2+}$ in the bath is related to the percentage of iron in the deposited alloy. Although there is an obvious relation between these quantities, and the iron content of the alloy certainly decreases with the calculated $\mathrm{Fe}^{2+}$ concentration in the bath, the uncertainty in the linear fit (mainly due to uncertainties related to the EDX measurements) is too large make any real predictions of the exact alloy composition. 


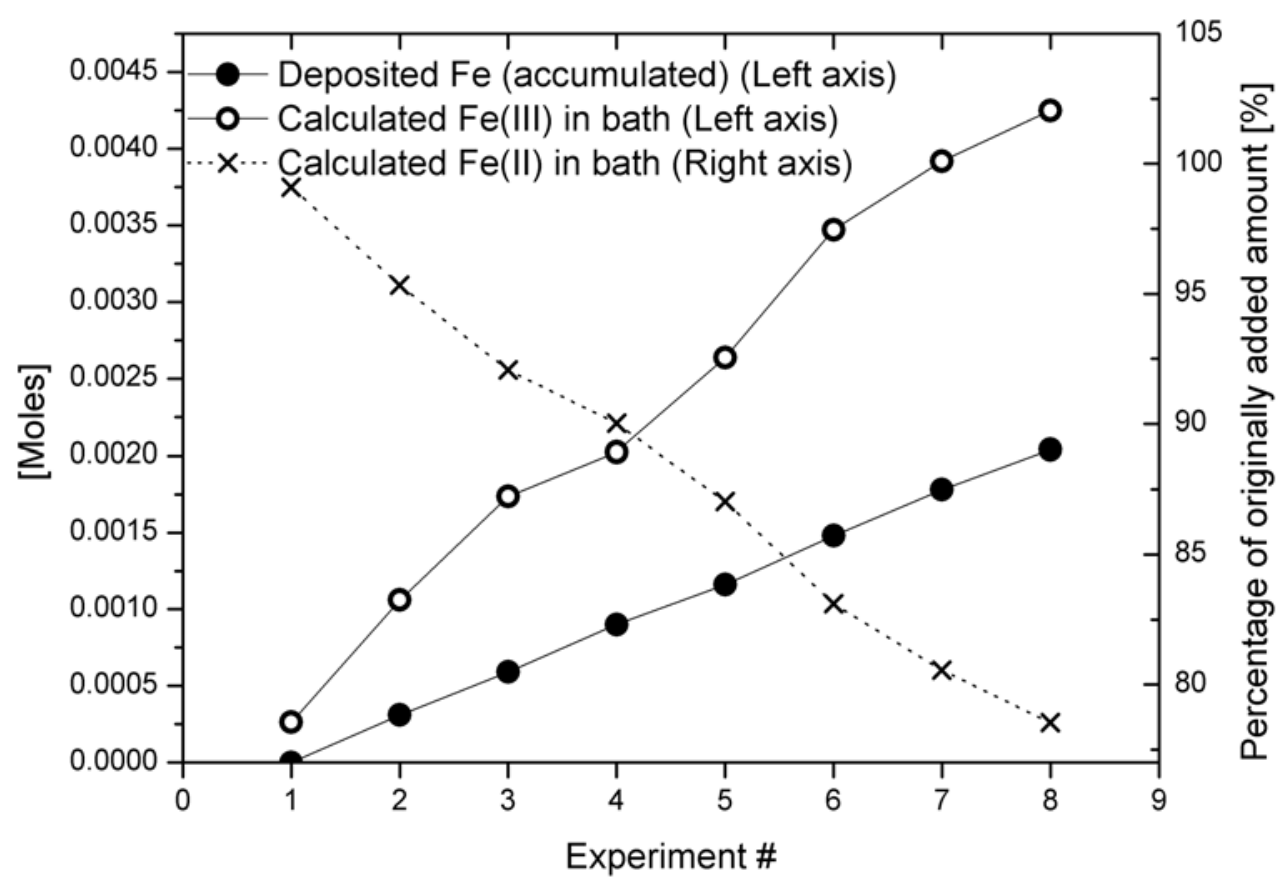

Figure 6: Development of Fe content in the bath. Spectrophotometric measurements of $\mathrm{Fe}^{3+}$, deposit weight and composition allows for calculations of the remaining amount of $\mathrm{Fe}^{2+}$ in the bath.

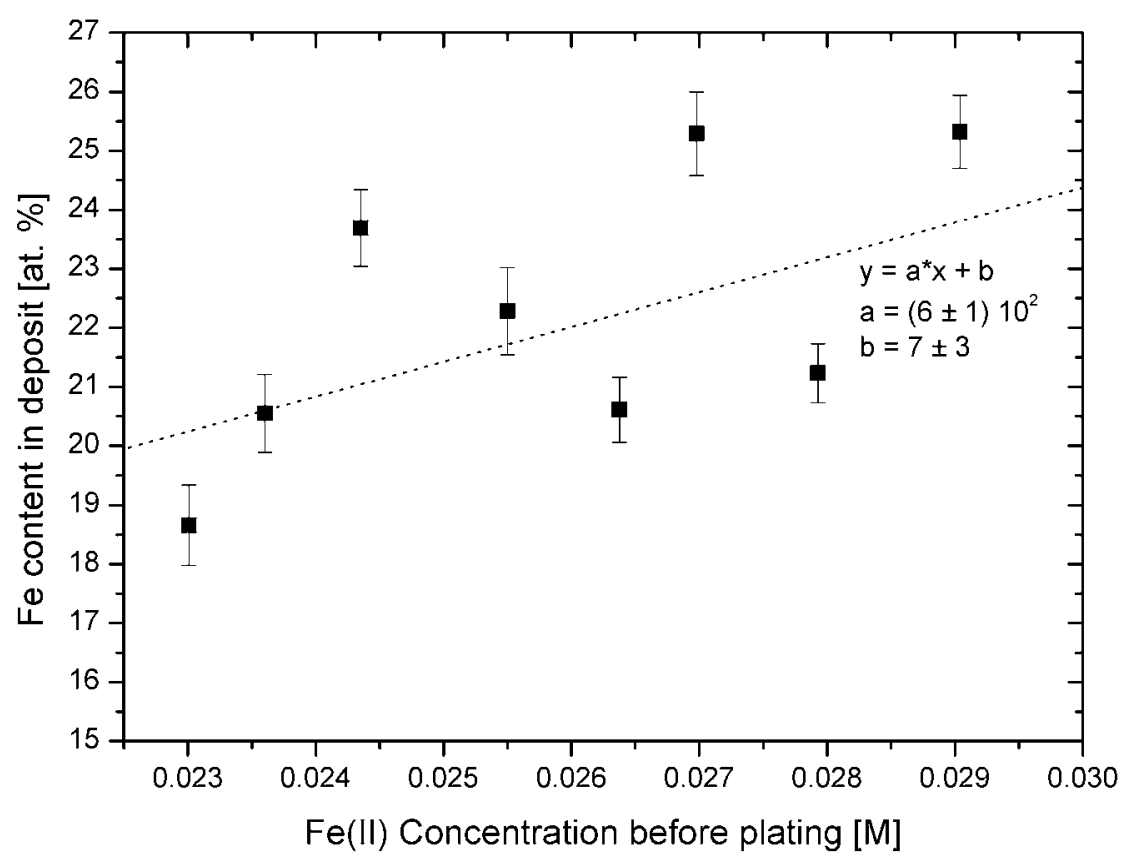

Figure 7: Fe content in deposits as a function of $\mathrm{Fe}^{2+}$ concentration in the bath. When the amount of deposited metal is known, the concentration of $\mathrm{Fe}^{3+}$ ions is computed from the standard curve in Figure 5, and when we know the initial amount of Fe ions, we can calculate the amount of available $\mathrm{Fe}^{2+}$ ions. In the included fit ' $\mathrm{x}$ ' denotes the $\mathrm{Fe}$ (II) concentration before plating, and ' $y$ ' denotes the iron content in the deposit. Suitable units on ' $a$ ' and 'b' are implied. 


\section{Conclusion}

A reliable and stable Permalloy plating bath is presented, which is suitable for MEMS applications due to low internal stress, good magnetic properties and long term bath stability - even without using nitrogen purging or other means to remove oxygen dissolved in the electrolyte. The bath is especially well suited in situations, where the bath is only used every once in a while, such that continuous bath replenishment is not feasible.

We have demonstrated a way to monitor the amount of available $\mathrm{Fe}^{2+}$ ions in the bath, allowing for simple bath maintenance by regular addition of iron (sulfate or chloride) and $\mathrm{pH}$ adjustments (diluted hydrochloric or sulfuric acid). When operating our 251 version of the bath, we have found that it is helpful to electroplate for a few hours on a dummy wafer before electroplating on real samples. This reactivates the anode, and as we have seen some of the $\mathrm{Fe}^{3+}$ ions will be reduced to $\mathrm{Fe}^{2+}$. With typical use the bath will then be able to last for more than 1 year.

\section{Acknowledgments}

Kristian Smistrup acknowledges support from Copenhagen School of Nanotechnology (C:O:N:T), and Danish Technological Institute.

\section{References}

1. J.V. Powers \& L.T. Romankiw, US 3,652,442, March 28 (1972)

2. E.E. Castellani, J.V. Powers \& L.T. Romankiw, US 4,102,756, Juli 25 (1978)

3. T. Osaka et al., "Influence of Crystalline Structure and Sulfur Inclusion on Corrosion Properties of Electrodeposited CoNiFe Soft Magnetic Films", J. Electrochem. Soc., Vol. 146, No. 6, pp. 2092-2096 (1999)

4. A.F. Bogenschütz \& U. Georg, "Galvanische Legierungsabscheidung and Analytik" (in German), Eugen G. Leuze Verlag, Saulgau (1982)

5. A. Brenner, "Electrodeposition of Alloys", Academic Press, New York (1963)

6. J. Horkans, "Effect of Plating Parameters on Electrodeposited NiFe", J. Electrochem. Soc. Vol. 128, No. 1, pp. 44-49 (1981)

7. H.V. Venkatasetty, "Electrodepostion of Thin Magnetic Permalloy Films", J. Electrochem. Soc., Vol. 117, No. 3, pp. 403-407 (1970)

8. D.J. Sadler, T.M. Liakopoulos \& C.H. Ahn, "A Universal Electromagnetic Microactuator Using Magnetic Interconnection Concepts", J. Microelectromech. Syst. Vol. 9, No. 4, pp. 460-468 (2000)

9. M. Ruan, J. Shen \& C.B. Wheeler, "Latching microelectromagnetic relays", Sensors \& Actuators A, Vol. 91 pp. 346-350 (2001)

10. C. Liu, T. Tsao, Y-C Tai, T-S Leu, C-M Ho, W-L Tang \& D. Miu, "Out-of-plane Permalloy Magnetic Actuators for Delta-Wing Control", Proc. IEEE Micro Electro Mechanical Systems 1995 pp. 7-12 (1995)

11. E.J. O'Sullivan et al., "Integrated, variable reluctance magnetic micromotor", IBM J. Res. Dev. Vol. 42, No. 5, pp. 681-691 (1998) 
12. C. Liu, "Development of surface micromachined magnetic actuators using electroplated permalloy", Mechatronics Vol. 8, pp. 613-633 (1998)

13. K. Smistrup, P.T. Tang, O. Hansen \& M.F. Hansen, "Microelectromagnet for magnetic manipulation in lab-on-a-chip systems", J. Magn. Magn. Mat. Vol. 300, pp. 418-426 (2006)

14. K. Smistrup, B.G. Kjeldsen, J.L. Reimers, M. Dufva, J. Petersen \& M.F. Hansen, "On-chip magnetic bead microarray using hydrodynamic focusing in a passive magnetic bead separator", Lab Chip, Vol. 5, pp. 1315-1319 (2005)

15. K. Smistrup, T. Lund-Olesen \& M.F. Hansen, "Microfluidic magnetic separator using an array of soft magnetic elements", J. Appl. Phys. Vol. 99, No. 8 (2006)

16. J.G. Speight, "Lange's Handbook of Chemistry", McGraw-Hill, New York (2005)

17. F.E. Rasmussen, J.T. Ravnkilde, P.T. Tang, O. Hansen, \& S. Bouwstra, "Electroplating and characterization of cobalt-nickel-iron and nickeliron for magnetic micro-system applications", Sensors \& Actuators A, Vol. 92 pp. 242-248 (2001)

18. R.J. Lash, "Electroplating Iron Group Metal Alloys", US 4,129,482 patent, Dec. 12 (1978)

19. K. Korsbæk \& R. Rubæk, "Udvikling og karakterisering af magnetiske legeringer til mikromekaniske komponenter" (in Danish), master thesis at IPL, Technical University of Denmark (2004)

20. P. Kofstad, "Uorganisk kjemi" (in Norwegian), H. Aschehoug \& Co., Lund (1979) 